\title{
ПОНЯТІЙНО-ТЕРМІНОЛОГІЧНИЙ АНАЛІЗ КАТЕГОРІЇ «МЕХАНІЗМИ ДЕРЖАВНОГО УПРАВЛІННЯ»
}

У даній роботі проведено аналіз змісту категорії «механізми державного управління» з позииї системного підходу. Визначено, щчо дослідники розглядають механізм державного управління з погляду різних підходів: соціологічного, діалектичного, сутнісного. Спираючись на аналіз наукових праць, в яких автори наводять своє трактування визначення поняття «механізми державного управління» встановлено, щзо здебільшого механізми державного управління розглядаються як сукупність норм, методів, важелів, засобів, стимулів, інструментів, за допомогою яких органи державного управління виконують функиї та завдання, щуо покладено на них. Отже, механізми державного управління розглядають як практичні заходи, засоби, важелі і стимули, за допомогою яких органи державної влади впливають на суспільство, виробниитво, будь-яку соціальну систему з метою досягнення поставлених цілей. Здебільшого схема реального механізму державного управління містить цілі, рішення, впливи, діі, результати. Основними видами механізмів державного управління вченими визначаються політичний, економічний, матеріально-технічний, нормативно-правовий, організаційний та інформаційноаналітичний механізм державного управління. дослідження сутності категорії «механізми державного управління» показало, щчо прочеси державного управління забезпечуються відповідними механізмами, які мають динамічний характер сукупності певних дій, та підпорядковані встановленій меті, иілям та завданням, причому залежно від управлінських процесів змінюється $і$ дія механізмів державного управління. Концептуалізація змісту категорії «механізм державного управління» в сукупності дозволяє нам визначити механізм державного управління як систему взаємопов'язаних складових, які, взаємодіючи між собою, впливають на об 'єкт управління.

Ключові слова: державне управління, механізми, аналіз, сутність, зміст, ресурси.

М. Н. СИКОРСКИЙ

Херсонский национальный технический университет ORCID: 0000-0002-0670-8005

У. В. МАЛЬЦЕВ

Херсонский национальный технический университет ORCID: 0000-0002-6241-938X

Д.А. ЛОГАЧЕВ

Херсонский национальный технический университет ORCID: 0000-0002-5503

Ю.А. СТЕЛЬМАШЕНКО

Херсонский национальный технический университет ORCID: 0000-0002-5038-2268

\section{ПОНЯТИЙНО-ТЕРМИНОЛОГИЧЕСКИЙ АНАЛИЗ КАТЕГОРИИ «МЕХАНИЗМЫ ГОСУДАРСТВЕННОГО УПРАВЛЕНИЯ»}

В данной работе проведен анализ содержания категории «механизмы государственного управления» с позиции системного подхода. Определено, что исследователи рассматривают механизм государственного управления с точки зрения различных подходов: социологического, диалектического, сущзностного. Опираясь на анализ научных работ, в которых авторы приводят свою трактовку определения понятия «механизмы государственного управления» установлено, что в основном механизмы государственного управления рассматриваются как совокупность норм, методов, рычагов, 
средств, стимулов, инструментов, с помощью которых органьл государственного управления выполняют функции и задачи, возложена на них. Таким образом, механизмы государственного управления рассматривают как практические меры, средства, рычаги и стимуль, с помошью которых органы государственной власти влияют на общество, производство, любую сочиальную систему с целью достижения поставленных иелей. В основном схема реального механизма государственного управления содержст иели, решения, влияния, действия, результаты. Основными видами механизмов государственного управления ученыли определяются политический, эконолический, материальнотехническое, нормативно-правовой, организационный и информационно-аналитический механизм государственного управления. исследования сущности категории «механизмы государственного управления» показало, что прочессы государственного управления обеспечиваются соответствуюшими механизмами, которые имеют динамичный характер совокупности определенных действий, $и$ подчиненные установленной иели, иелям и задачам, причем в зависимости от управленческих процессов меняется и действие механизмов государственного управления. Концептуализация содержания категории «механизм государственного управления» в совокупности позволяет нам определить механизм государственного управления как систему взаимосвязанных составляюших, которые, взаимодействуя между собой, влияют на объект управления.

Ключевые слова: государственное управление, механизмы, анализ, сущность, содержание, pecypcbl.

M. M. SIKORSKY

Kherson National Technical University ORCID: 0000-0002-0670-8005

U. V. MALTSEV

Kherson National Technical University ORCID: 0000-0002-6241-938X

D. A. LOGACHEV

Kherson National Technical University ORCID: 0000-0002-5503

YU. A. STELMASHENKO

Kherson National Technical University ORCID: 0000-0002-5038-2268

\section{CONCEPTUAL AND TERMINOLOGICAL ANALYSIS OF THE "MECHANISMS OF PUBLIC ADMINISTRATION" CATEGORY}

This paper analyzes the content of the category "mechanisms of public administration" from the position of a systematic approach. It was determined that researchers consider the mechanism of public administration from the point of view of various approaches: sociological, dialectical, essential. Based on the analysis of scientific works in which the authors give their interpretation of the definition of the concept of "mechanisms of public administration", it is established that basically the mechanisms of public administration are considered as a set of norms, methods, levers, means, incentives, tools with which government bodies perform functions and the tasks entrusted to them. So, the mechanisms of public administration are considered as practical measures, means, levers and incentives with the help of which public authorities influence society, production, any social system in order to achieve their goals. Basically, the diagram of the real mechanism of public administration contains goals, decisions, influences, actions, results. The main types of mechanisms of public administration by scientists are determined by the political, economic, material and technical, regulatory, organizational, informational and analytical mechanism of public administration. studies of the essence of the category "mechanisms of public administration" showed that the processes of public administration are provided by appropriate mechanisms that have a dynamic nature of a set of certain actions, and are subordinate to a set goal, goals and objectives, and depending on management processes, the action of public administration mechanisms also changes. Conceptualization of the content of the category "mechanism of public administration" in the aggregate allows us to define the mechanism of public administration as a system of interrelated components that, interacting with each other, affect the object of management.

Key words: public administration, mechanisms, analysis, essence, content, resources.

\section{Постановка проблеми}

Сучасний розвиток науки державного управління пов'язаний 3 удосконаленням понятійно-категоріального апарату, що має правильно відображати зміст її проблемного кола та сприяти теоретичному пізнанню та практичному вирішенню завдань науки державного управління. Одним із найвагоміших визначень учені визнають категорію «механізм державного управління», яка посіла місце широкого об’єкта дослідження в розрізі галузі публічного управління та адміністрування. 
Учені зазначають, що без розкриття категорії «механізми державного управління» неможливо вирішити проблему підвищення його ефективності, адже ефективність системи державного управління залежить від наявності ефективних функційних механізмів, що дозволяють забезпечити скоординоване, цілеспрямоване та дієве керівництво суспільними процесами держави; належний організаційноуправлінський вплив на суспільний розвиток держави; реалізацію цілей та завдань державного управління - як загальних, так і персоніфікованих, які слід вирішувати в конкретних сферах суспільного життя. Виходячи з вищесказаного, актуальним постає питання визначення змісту механізмів державного управління та їх класифікації [1].

\section{Аналіз останніх досліджень і публікацій}

Суттєві напрацювання концептуального апарату механізмів державного управління, чисельні праці, присвячені його наповненню та термінологічному змісту, створюють достатні передумови дослідження категорії «механізми державного управління» як складової системи державного управління. Сьогодні важко знайти наукове дослідження в галузі державного управління, в якому в тому чи іншому вигляді не використовується категорія «механізми державного управління». До питань ії смислового наповнення та сутнісних характеристик зверталися та звертаються багато вітчизняних та зарубіжних науковціi. Провідні вчені Г. Атаманчук, В. Бакуменко, Д. Безносенко, О. Коротич, О. Кравченко, С. Крисюк， С. Малиновський， В. Мороз， Н. Нижник， Л. Паращенко， Л. Приходченко， О. Радченко, Р. Рудницька, О. Сидорчук, В. Федоренко, О. Федорчак, В. Філіппова своїми дослідженнями сприяли формуванню концепції «механізми державного управління». Однак, незважаючи на значну увагу науковців, питання теоретико-прикладного аналізу сутностей механізмів державного управління, досі залишається актуальним.

\section{Формулювання мети дослідження}

Виходячи $з$ вищесказаного, метою нашого дослідження $є$ понятійно-термінологічний аналіз категорії «механізми державного управління» з позиції системного підходу.

\section{Викладення основного матеріалу дослідження}

Механізми державного управління як важлива складова процесу державного управління, спрямованого на проведення в життя державної стратегії та політики, є «похідними» від держави, що сьогодні розглядається як багатофункціональна соціальна система.

Поміж науковцями існує думка, що в управлінні майже всі його елементи можна назвати механізмами. Так, В. Філіппова у своєму дослідження зазначає, що більшістю науковців «механізм» визначається як загальнонаукове, багатоаспектне й всеохоплююче поняття, що характеризує матеріальні об’єкти та їх взаємодію на всіх рівнях організації матерії, характеризує процеси управління й саморегулювання в живій природі та суспільстві [2].

О. Радченко зазначає, що механізму як такому мають бути обов'язково притаманними такі ознаки: він є продуктом організованої діяльності; він має мету або функцію; він містить послідовність дій, певний вид руху; він передбачає переважно однобічний вплив із чітко визначеним вектором впливу; він має суб'єкт і об'єкт; він характеризується жорстким взаємозв'язком, усталеністю процесу, правил взаємодії; його функціонування в ідеалі націлене на автоматизм; його побудова носить структурнофункціональний характер; він має ознаки відкритої або закритої системи [3, с.20]. При цьому розвиваючи основні положення, дослідник зауважує, що механізми державного управління $є$ системною сукупністю інституцій, структур, послідовних дій, форм, станів і процесів у державі як продукт організованої людської діяльності, що має на меті реалізацію інтересів і потреб людей та розв'язання нагальних суспільно-політичних проблем за рахунок державного впливу й регулювання суспільної життєдіяльності на основі усталених суспільних цінностей, норм і правил; є формою реалізації функцій держави та має суб'єктом органи державного управління» [4].

Дослідники розглядають механізм державного управління з погляду різних підходів.

Так, соціологічний підхід розглядає механізм державного управління як взаємозв'язок елементів, процесів, закономірностей, завдяки якому суб'єкт державного управління задовольняє потреби суспільства шляхом ухвалення відповідних управлінських рішень.

Діалектичний підхід розглядає механізм державного управління як засіб вирішення протиріч, що виникають у реальності і являє собою процес послідовних дій 3 їх вирішення 3 використанням відповідних управлінських методів для досягнення певної мети.

Сутнісний підхід інтерпретує механізм державного управління через системні властивості суб'єкта та об'єкта управління і включає в себе: цілі управління, елементи об'єкта, на який здійснюється вплив, дії для досягнення цілей, методи впливу, матеріальні та фінансові ресурси управління, соціальної та організаційний потенціал. Зрештою, комплексний підхід розуміє механізм державного управління відповідно до його функціонального призначення з управлінського впливу (організаційно-правовий, фінансово-економічний, інституційний і т.п.).

Виходячи з цього, механізми державного управління розглядають як практичні заходи, засоби, важелі і стимули, за допомогою яких органи державної влади впливають на суспільство, виробництво, 
будь-яку соціальну систему 3 метою досягнення поставлених цілей. Схема реального механізму державного управління містить цілі, рішення, впливи, дії, результати. Комплексний механізм державного управління вони визначають як систему політичних, економічних, соціальних, організаційних і правових засобів цілеспрямованого впливу органів державного управління [5, с.125]. До цього можна додати характеристику, що механізми державного управління мають конкретний характер i що кожен конкретний механізм має розглядатися як сукупність взаємоузгоджених методів управління [6, с.81-82].

Визначення змісту та засобів використання С. Крисюком поняття «механізм державного управління» надає підстави зробити висновок про переважання інституційного уявлення про механізм державного управління як «засобів, важелів, методів і стимулів», які використовуються в управлінні, про що і свідчить його справедлива оцінка сучасного стану державного управління як такого, що «еклектично поєднує в собі як інститути, успадковані від радянської командно-адміністративної системи, так і нові, сформовані вже за роки незалежності, які не завжди відповідають стандартам демократичної правової держави з соціально орієнтованою ринковою економікою» [7, с. 5-6].

Також «механізм державного управління» визначають як: інструмент реалізації функцій держави та іiі виконавчої влади [8]; практичні заходи, засоби, важелі, стимули, за допомогою яких органи державної влади впливають на будь-які суспільні відносини для досягнення поставлених цілей [9]; комплексна система державного управління, до складу якої входять конкретні механізми управління (економічний, мотиваційний, політичний, правовий тощо), які в сукупності здатні забезпечити збалансоване та ефективне функціонування єдиного державного механізму [10]; сукупність засобів організації управлінських процесів та способів впливу на розвиток керованих об'єктів із використанням відповідних методів управління, спрямованих на реалізацію цілей державного управління [11]; механізм як система, призначена для практичного здійснення державного управління та досягнення поставлених цілей, котра має певну структуру, методи, важелі, інструменти впливу на об'єкт управління 3 відповідним правовим, нормативним та інформаційним забезпеченням [12].

Р. Рудніцька, О. Сидорчук, О. Стельмах визначають механізм державного управління як штучно створену складну систему, призначену для досягнення поставлених цілей, яка має визначену структуру, сукупність правових норм, методи, засоби, інструменти державного впливу на об'єкт управління [13, с. 15]. У свою чергу, Н. Нижник та О. Машков механізми державного управління визначають, як складову частину системи управління, що забезпечує вплив на внутрішні (коли йдеться про механізм управління організацією) та зовнішні (коли говорять про механізм взаємодії з іншими організаціями) фактори, від стану яких залежить результат діяльності управлінського об'єкта [14].

Схоже визначення знаходимо у О. Федорчак, яка доводить, що механізм державного управління - це механізм як система, призначена для практичного здійснення державного управління та досягнення поставлених цілей, яка має визначену структуру, методи, важелі, інструменти впливу на об'єкт управління $з$ відповідним правовим, нормативним та інформаційним забезпеченням [15]. На основі існуючих досліджень дослідниця подає узагальнену класифікацію механізмів державного управління. На думку О. Федорчак, механізми державного управління поділяються на механізми за функціональним призначенням та механізми за суб'єктом управління. Відповідно за функціональним призначенням економічні, мотиваційні, організаційні, політичні та правові, а за суб'єктом управління - механізми, які використовуються законодавчими органами державної влади, президентом України, органами виконавчої влади, органами судової влади, органами місцевої влади [15].

О. Коротич розрізняє механізми державного управління за суб'єктами управління. Авторка вважає, що в Україні механізми державного управління поділяються на такі, які здійснюються органами управління: вищий рівень (ВРУ, Президент, КМУ); обласного рівня (обласними радами, обласними державними адміністраціями); районного рівня (районними радами, районними державними адміністраціями); місцевого рівня (міськими, селищними, сільськими радами) [16].

Враховуючи та узагальнюючи тлумачення дефініції «механізми державного управління», В. Філіппова охарактеризувала їх як складну систему, спрямовану на досягнення і реалізацію цілей державної політики, яка охоплює систему органів державної влади та місцевого самоврядування, законодавчі, правові норми та сукупність взаємопов'язаних форм, методів, інструментів і важелів формування та використання різноманітних ресурсів на основі комплексної системи індикаторів розвитку певної галузі [2].

Л. Приходченко виділяє в механізмі державного управління цільові, нормативно-правові, організаційні, економічні та інформаційні складові. Цільові складові є первинними елементами у структурі механізму, призначення якого полягає в достатній конкретизації загальної мети управління. Останнє забезпечується шляхом іiї декомпозиції (поділу на складові частини) та побудови ії ієрархічної структури (дерево цілей). Важливим аспектом цієї складової $є$ те, що функції державного управління $\epsilon$ похідними від цілей і надають змогу вирішувати покладені завдання, цілеспрямовано впливаючи на об’єкт управління [17, с.3]. 
Вивчаючи питання державного управління Л. Паращенко наголошує, що «механізми державного управління є категорією управління, яка відображає складні для однозначної ідентифікації частини державно-управлінської системи, які включають цілі управління, ресурси управління, соціальний та організаційний потенціали, взаємозв'язки різних елементів управління, за допомогою яких здійснюється вплив у суб'єктно-об'єктних взаємодіях». 3 огляду на багатозначність поняття «механізми державного управління», дослідниця робить висновок про неможливість однозначного виокремлення в системі державного управління феноменів, які можна назвати його механізмами. Як вважає Л. Паращенко, критерієм виділення в системі державного управління його механізмів $\epsilon$ певна послуга чи вид/група/тип послуг, які має надавати система державного управління [18].

У своїх дослідженнях Л. Юзьков визначає механізм державного управління як організацію практичного здійснення державного управління. На його думку, механізм управління включає в себе: об'єкти управління; суб'єкти управління; взаємовплив між суб'єктами та об'єктами управління. Статику механізму управління визначають суб'єкти та об’єкти управління, які становлять організаційноструктурну основу механізму державного управління, а динаміку - комплекс зв'язків та взаємодій між ними» [19, с.57-59].

Подібної думки дотримуються С. Мороз, Л. Грень та В. Мороз, які наголошують, що механізм державного управління являє собою інституційно оформлену, організаційно структуровану і суспільно схвалену (визнану суспільством) систему суб'єктів та об'єктів державного управління в їх сукупності 3 методами, інструментами, формами i способами взаємодії (нормативно-правові, організаційноадміністративні, інформаційно-технологічні елементи), а також конкретними діями по досягненню суспільно значущих цілей. Іншими словами, вчені вважають, що система механізму державного управління може бути розглянута через призму діалектичної єдності суб'єктів державного управління (органи державної влади та їх посадові особи), технологій формування та реалізації управлінських рішень, а також необхідних для цього інструментів та ресурсів (правові, фінансові, адміністративні, людські тощо). Також дослідники наголошують, що механізм державного управління є структурованою єдністю суб'єктів державного управління та їх впливів (алгоритми і процедури реалізації функцій управління, технології управління, методи і інструменти формування і реалізації управлінських рішень) на об'єкти державного управління 3 метою реалізації функцій держави і досягнення цілей його функціонування» [20, с.17-18].

Інші вчені наголошують на можливості поділу механізмів державного управління на адміністративні (організаційно-розпорядчі), правові, економічні, політичні, соціально-психологічні та морально-етичні або інституційні, політичні, економічні, культурні, юридичні (нормативно-регулятивні), матеріально-технічні, бюджетно-фінансові та духовні (ідеологічні) [21, с. 122-123].

У свою чергу, Ю. Кунєв розглядає структуру механізму державного управління як сукупність шести складових: діяльність;

- цільова частина - сукупність всіх цілей, на реалізацію яких спрямована управлінська

- функціональна частина - види управлінської діяльності (пізнавально-програмні та організаційно регулятивні), необхідні для виконання основних функцій організації;

- методологічна частина - ті методи, які використовуються при виконанні всіх видів управлінської діяльності, тобто забезпечують виконання функціональної частини;

- частина, що відображає сукупність принципів - норми або правила, по яких потрібно здійснювати успішну управлінську діяльність;

- інструментальна частина - управлінські рішення, повноваження, засоби інформаційноматеріально-енергетичного впливу на об’єкт управління;

- технологічна частина - технологія підготовки прийняття та виконання управлінських рішень [22, с. 247].

Узагальнюючи теоретичні підходи до визначення поняття «механізми державного управління», ми маємо погодитися $з$ твердженням А. Березянської, що «ефективність системи державного управління залежить від наявності успішно функціонуючих механізмів, які дозволяють забезпечити: скоординоване, цілеспрямоване та дієве керівництво суспільними процесами держави; належний організаційноуправлінський вплив на суспільний розвиток держави; реалізацію цілей та завдань державного управління - як загальних, так і персоніфікованих, які необхідно вирішувати в конкретних сферах суспільного життя» [23].

\section{Висновки}

Отже, дослідження сутності категорії «механізми державного управління» показало, що процеси державного управління забезпечуються відповідними механізмами, які мають динамічний характер сукупності певних дій, та підпорядковані встановленій меті, цілям та завданням, причому залежно від управлінських процесів змінюється і дія механізмів державного управління. Концептуалізація змісту категорії «механізм державного управління» в сукупності дозволяє нам визначити механізм державного 
управління як систему взаємопов'язаних складових (інструментів, методів, засобів, важелів), які, взаємодіючи між собою, впливають на об'єкт управління.

Подальшим напрямом наукових досліджень із розглянутої проблематики вважаємо проведення дослідження щодо уточнення визначення та структури комплексного механізму державного управління.

\section{Список використаної літератури}

1. Артем’єв, О. С. Узагальнення класифікації та теоретичних підходів до визначення поняття механізм державного управління. Теорія та практика державного управління $i$ місцевого самоврядування, 2019. №1. URL : $\underline{\text { http://el-zbirn-du.at.ua/2019_1/2/8.pdf }}$

2. Філіппова, В. Д. Термінологічний аналіз сутності механізму державного управління системою педагогічної освіти. Науковий вісник Академії муніциипального управління. Серія: Управління, 2014. №2. C.148-157.

3. Радченко О. Родові ознаки категорії «механізм» в соціальних науках. Публічне управління: теорія та практика, 2013. № 3. С. 19-25.

4. Радченко О. В. Категорія «механізм» у системі державного управління. Держава та регіони. Серія: Державне управління, 2009. № 3. С. 64-69.

5. Державне управління: словник-довідник / За заг. ред. В.М. Князєва, В.Д. Бакуменка. К.: Видво УАДУ, 2002. 228 с.

6. Коротич О. Механізми державного управління : проблеми теорії та практичної побудови. Вісник Національної Академії державного управління, 2006. № 3. С.79-84.

7. Крисюк С.В. Державне управління освітою: навч. посібник. К.: НАДУ, 2009. 220 с.

8. Атаманчук Г. В. Теория государственного управления : курс лекций. 3-е изд., доп. М. : ОМЕГА-Л, 2005. 584 c.

9. Бакуменко В. Д. Безносенко Д. О. Виявлення комплексу проблем державного управління процесами європейської та євроатлантичної інтеграції України, розробка пропозицій щодо вдосконалення системи державного управління цими процесами: науково-дослідна робота. К. : НАДУ при Президентові України ; Центр навчання і досліджень 3 європейської та євроатлантичної інтеграції України. $41 \mathrm{c}$.

10. Кравченко О. М. Теоретичні підходи до визначення поняття “механізм державного управління”. Державне управління: удосконалення та розвиток : електронне наукове фахове видання, 2009. № 3. URL: http://www.dy.nayka. com.ua/index.php? operation=1\&iid=56.

11. Малиновський В. Я. Державне управління : навч. посібн. 2-ге вид., доп. та перероб. К. : Атіка, 2003. $576 \mathrm{c.}$

12. Федоренко В. Г., Діденко О. М., Руженський М. М., Іткін О. Ф. Політична економія : підручник / за наук. ред. В. Г. Федоренка. К. : Алерта, 2008. 487 с.

13. Рудницька Р. М., Сидорчук О. Г., Стельмах О. М. Механізми державного управління: сутність і зміст. Львів : ЛРІДУ НАДУ, 2005. 28 с.

14. Нижник Н.Р., Машков О.А. Системний підхід в організаціях державного управління: навч. посіб. / За заг. ред. Н.Р. Нижник. К.: Вид-во УАДУ, 1998. 159 с.

15. Федорчак О.В. Класифікація механізмів державного управління. Демократичне врядування, 2008. № 1. URL: http://lvivacademy.com/vidavnitstvo_1/visnik/ fail/O_Fedorchak.pdf

16. Коротич О.Б. Класифікація та зміст механізмів управління державою. Актуальні проблеми державного управління: зб. наук. пр. ОРІДУ. Одеса, 2006. Вип. 2 (26). С. 122-128.

17. Приходченко Л.Л. Структура механізму державного управління: взаємозв'язок компонентів та фактори впливу на ефективність. Вісник Національної академї державного управління при Президентові України, 2009. Вип. 2. С. 105-112.

18. Паращенко Л. І. Механізм державного управління загальною середньою освітою в контексті національної стратегії розвитку освіти. Державне управління: удосконалення та розвиток: електрон. наук. фах. вид., 2012. № 1. URL: http://www.dy.nayka.com.ua/?op=1\&z=382.

19. Юзьков Л.П. Государственное управление в политической системе развитого социализма. К.: Вища шк., 1983. 155 с.

20. Мороз С. А., Грень Л. Н., Мороз В. М. Концептуализация категории «механизмы государственного управления» через призму анализа содержания феномена «механизм» в экономических, юридических и технических науках. Научный журнал Академии государственного управления Республики Армения «Публичное управление», 2019. №1. С.10-19.

21. Коротич О.Б. Класифікація та зміст механізмів управління державою. Актуальні проблеми державного управління: зб. наук. пращь. Одеса: ОРІДУ НАДУ, 2006. Вип. 2 (26). с. 122-128.

22. Кунєв Ю. Д. Управление в таможенной службе. К.: Центр навчальної літератури, 2006. 408 с. 
23. Березянська А. О. Теоретичні підходи до визначення поняття «механізми державного управління» та їх класифікація. Наукові праці. Державне управління. 2015. Вип. 242. Т. 254. C.6-10. URL: http://official.chdu.edu.ua/article/viewFile/60593/56337

\section{References}

1. Artemiev, O. S. (2019) Uzahalnennia klasyfikatsii ta teoretychnykh pidkhodiv do vyznachennia poniattia mekhanizm derzhavnoho upravlinnia. Teoriia ta praktyka derzhavnoho upravlinnia $i$ mistsevoho samovriaduvannia. No 1. URL : http://el-zbirn-du.at.ua/2019_1/2/8.pdf

2. Filippova, V. D. (2014) Terminolohichnyi analiz sutnosti mekhanizmu derzhavnoho upravlinnia systemoiu pedahohichnoi osvity. Naukovyi visnyk Akademii munitsypalnoho upravlinnia. Seriia: Upravlinnia, 2014. No 2. pp.148-157.

3. Radchenko O. (2013) Rodovi oznaky katehorii «mekhanizm»v sotsialnykh naukakh. Publichne upravlinnia: teoriia ta praktyka. No 3. pp. 19-25.

4. Radchenko O. V. (2009) Katehoriia «mekhanizm» u systemi derzhavnoho upravlinnia. Derzhava ta rehiony. Seriia: Derzhavne upravlinnia. No 3. pp. 64-69.

5. Derzhavne upravlinnia: slovnyk-dovidnyk / Za zah. red. V.M. Kniazieva, V.D. Bakumenka. (2002) Kyiv: Vyd-vo UADU. 228 p.

6. Korotych O. (2006) Mekhanizmy derzhavnoho upravlinnia : problemy teorii ta praktychnoi pobudovy. Visnyk Natsionalnoi Akademii derzhavnoho upravlinnia. No 3. pp.79-84.

7. Krysiuk S.V. (2009) Derzhavne upravlinnia osvitoiu: navch. posibnyk. Kyiv: NADU. 220 p.

8. Atamanchuk H. V. (2005) Teoryia hosudarstvennoho upravlenyia : kurs lektsyi. 3-e yzd., dop. Moskva: OMEHA-L. 584 p.

9. Bakumenko V. D. Beznosenko D. O. Vyiavlennia kompleksu problem derzhavnoho upravlinnia protsesamy yevropeiskoi ta yevroatlantychnoi intehratsii Ukrainy, rozrobka propozytsii shchodo vdoskonalennia systemy derzhavnoho upravlinnia tsymy protsesamy: naukovo-doslidna robota. Kyiv : NADU pry Prezydentovi Ukrainy ; Tsentr navchannia i doslidzhen z yevropeiskoi ta yevroatlantychnoi intehratsii Ukrainy. 41 p.

10. Kravchenko O. M. (2009) Teoretychni pidkhody do vyznachennia poniattia "mekhanizm derzhavnoho upravlinnia". Derzhavne upravlinnia: udoskonalennia ta rozvytok : elektronne naukove fakhove vydannia. No 3. URL: http://www.dy.nayka. com.ua/index.php? operation=1\&iid=56.

11. Malynovskyi V. Ya. (2003) Derzhavne upravlinnia : navch. posibn. 2-he vyd., dop. ta pererob. Kyiv: Atika. 576 p.

12. Fedorenko V. H., Didenko O. M., Ruzhenskyi M. M., Itkin O. F. (2008) Politychna ekonomiia : pidruchnyk / za nauk. red. V. H. Fedorenka. Kyiv : Alerta. 487 p.

13. Rudnytska R. M., Sydorchuk O. H., Stelmakh O. M. (2005) Mekhanizmy derzhavnoho upravlinnia: sutnist i zmist. Lviv : LRIDU NADU. 28 p.

14. Nyzhnyk N.R., Mashkov O.A. (1998) Systemnyi pidkhid v orhanizatsiiakh derzhavnoho upravlinnia: navch. posib. / Za zah. red. N.R. Nyzhnyk. Kyiv: Vyd-vo UADU. 159 p.

15. Fedorchak O.V. (2008) Klasyfikatsiia mekhanizmiv derzhavnoho upravlinnia. Demokratychne vriaduvannia. No 1. URL: http://lvivacademy.com/vidavnitstvo_1/visnik/ fail/O_Fedorchak.pdf

16. Korotych O.B. (2006) Klasyfikatsiia ta zmist mekhanizmiv upravlinnia derzhavoiu. Aktualni problemy derzhavnoho upravlinnia: zb. nauk. pr. ORIDU. Odesa. Vol. 2 (26). pp. 122-128.

17. Prykhodchenko L.L. (2009) Struktura mekhanizmu derzhavnoho upravlinnia: vzaiemozviazok komponentiv ta faktory vplyvu na efektyvnist. Visnyk Natsionalnoi akademii derzhavnoho upravlinnia pry Prezydentovi Ukrainy. Vol. 2. pp. 105-112.

18. Parashchenko L. I. (2012) Mekhanizm derzhavnoho upravlinnia zahalnoiu serednoiu osvitoiu v konteksti natsionalnoi stratehii rozvytku osvity. Derzhavne upravlinnia: udoskonalennia ta rozvytok: elektron. nauk. fakh. vyd., No 1. URL: http://www.dy.nayka.com.ua/?op=1\&z=382.

19. Yuzkov L.P. (1983) Hosudarstvennoe upravlenye v polytycheskoi systeme razvytoho sotsyalyzma. Kyiv: Vyshcha shk. 155 p.

20. Moroz S. A., Hren L. N., Moroz V. M. (2019) Kontseptualyzatsyia katehoryy «mekhanyzmы hosudarstvennoho upravlenyia» cherez pryzmu analyza soderzhanyia fenomena «mekhanyzm» $\mathrm{V}$ эkonomycheskykh, yurydycheskykh y tekhnycheskykh naukakh. Nauchnbil zhurnal Akademyy hosudarstvennoho upravlenyia Respublyky Armenyia «Publychnoe upravlenye». No 1. pp.10-19.

21. Korotych O.B. (2006) Klasyfikatsiia ta zmist mekhanizmiv upravlinnia derzhavoiu. Aktualni problemy derzhavnoho upravlinnia: zb. nauk. prats. Odesa: ORIDU NADU. Vol. 2 (26). pp. 122-128.

22. Kuniev Yu.D. (2006) Upravlenye v tamozhennoi sluzhbe. Kyiv: Tsentr navchalnoi literatury. 408 p.

23. Berezianska A. O. (2015) Teoretychni pidkhody do vyznachennia poniattia «mekhanizmy derzhavnoho upravlinnia» ta yikh klasyfikatsiia. Naukovi pratsi. Derzhavne upravlinnia. Vol. 242. pp.6-10. URL: http://official.chdu.edu.ua/article/viewFile/60593/56337. 